reduced the incidence of epistaxes and gastro-intestinal haemorrhage without affecting the skin lesions, though the evidence for this is not convincing.

It must be remembered that for every claim for therapeutic success with these compounds a failure has been recorded. It is therefore impossible to forecast the success or failure in a given case. In view of the poor absorption, parenteral therapy may have more success than oral.

\section{Laryngismus Stridulus}

Q.-Can exposure to cold winds precipitate an attack of laryngismus stridulus? A healthy boy of 2 years has attacks when playing out of doors in the wind. If sheltered from the wind or taken indoors, he recovers and will immediately. resume playing as energetically as before the attack. During the attack there is obstruction to both inspiration and expiration, and a short dry cough develops. The child is pale and obviously distressed, and during the worst attack, according to his mother, became semi-conscious. The mother dates the present trouble from the whooping-cough inoculation, of which he received only the first inoculation, as it was followed by fever and " noisy breathing." She has been told to keep the child out of the wind and that he will grow out of the attacks. Should any further advice be given, and what treatment is advised during an attack? Is the inoculation likely to have played any part in the aetiology?

A.-Attacks of the nature described in children of this age can occur in the presence of minimal upper respiratory infection and be stimulated by cold. They are associated with allergic oedema of the subglottal tissues. It is desirable, however, that an expert laryngological examination be carried out. In the likely absence of organic disease of the larynx the condition of the nasopharynx should be reviewed and any septic foci treated. Nervous tension is very probably a contributory factor. Any possible source of emotional insecurity in the management or home esnvironment of the child should be remedied. The parents should be assisted to conceal their anxiety and to foster in themselves and the child a sense of confidence. Play with children of his own age should be encouraged, but physical and emotional fatigue avoided. Keeping the child out of the wind is justifiable. Temporary trial could be given to the use of a sedative-for example, chloral hydrate - at the time of strong winds. It is unlikely that a direct relation exists between inoculation and the attacks. Nervousness in the child, or allergic tendencies in the parents' families, may point to further preventive measures.

\section{Treatment of Chronic Pharyngitis}

Q. - What treatment is advised for a mild chronic atrophic pharyngitis causing persistent irritation in the throat? A part from the pharyngitis, E.N.T. examination is negative. Both smoking and drinking have been given up without effect, and "masterly inactivity" has proved unrevarding.

A.-In the great majority of cases of pharyngitis, one is concerned with a remote cause which is having a local effect. Treatment is thus a twofold problem. Many constitutional conditions are contributory-for example, rheumatism, dy'spepsia, anaemia, cardiac disease, and phthisis-and these may modify treatment. It is essential also to inquire into the patient's habits, surroundings, and type of work. Apart from smoking and alcohol, excessive dust or some other irritant in the atmosphere may be of aetiological importance. The presence of inflammation or suppuration in the upper air passages is a common cause, and besides eliminating unhealthy teeth and tonsils it is important to be sure that an E.N.T. examination has included radiological examination of the paranasal sinuses. Sinus infection must be treated before any improvement can be expected in the pharynx.

Besides avoiding tobacco and alcohol, the patient should eliminate condiments and highly seasoned foods. A morning dose of magnesia or sulphate of soda, a teaspoonful in a glass of hot water, is recommended. For a dry pharynx with tenacious mucus, an expectorant such as the following, three times a day, will give relief: Tincture of ipecacuanha, min. $12(0.7 \mathrm{ml}$.) ; antimonial wine, $\min .5(0.3 \mathrm{ml}$.) ; potassium iodide, gr. 3 (0.2 g.) ; syrup of tolu, min. 60 (3.5 ml.); water to 1 fl. oz. ( $28 \mathrm{ml}$.).

Locally, the throat may be treated with a warm alkaline solution, best sprayed through the nostrils. Counterirritation is applied by painting with iodine compound paint B.P.C. (Mandl's paint) or 5-10\% resorcin in glycerin. In severer cases the inflamed parts may be touched by the phvsician with iodine or $10 \%$ silver nitrate. Use of the galvano-cautery or diathermy to destroy red lymphoid nodules on the pharyngeal wall has also been advocated. The throat is painted first with $10 \%$ cocaine, after which the cautery point is used very sparingly on enlarged lymph nodes. These latter measures should be used only with the greatest care.

\section{Goat's Milk in Infantile Eczema}

Q.-Is there any truth in the alleged value of goat's milk in the treatment of infantile eczema?

A.- Infantile eczema is generally considered an allergic condition. There is evidence that foods, especially egg, milk, and wheat, are common allergens in this condition. If an infant or young child was allergic to the lactalbumen of cow's milk, then the complete replacement of cow's milk by goat's milk would result in the amelioration or clearing of the eczema.

\section{NOTES AND COMMENTS}

Swollen Ankles in Hot Weather.-Dr. J. H. Mitchell (Renfrewshire) writes: With reference to the answer on swollen ankles in hot weather ("Any Questions ?" September 3, p. 628), your expert suggests that "a change in environmental temperature increases the volume of the extracellular fluid of the whole body." From personal experience I should agree that this is so. Twice within the last two years I have come home to the United Kingdom by air from Egypt, involving a change in day shade temperature on each occasion of some $35^{\circ}$ F. $\left(19.5^{\circ}\right.$ C. $)$. I found that my wrist contracted by about $\frac{1}{4}$ in. $(6.4 \mathrm{~mm}$.) (manifest in my watchstrap needing adjusting), my waistline contracted by $\frac{3}{4}$ in. $(19 \mathrm{~mm}$.), and my feet shrank in volume considerablywhat had been tight-fitting shoes became loose-fitting. I noticed a marked difference also in the tightness of my Army cap-band. On the other hand my body weight on each occasion did not vary by $1 \mathrm{oz}$. $(28 \mathrm{~g}$.$) .$

Correction.-There were two mistakes in our report of Sir Henry Dale's tribute to Lord Horder at the Memorial Service held in St. Martin-in-the-Fields on September 5 (British Medical Journal. September 10, p. 686). Sir Henry spoke of the great number of people who would remember Lord Horder with grateful admiration for speeding the recovery of health and for making easier " what suffering had still to be borne." Later he described Lord Horder as a reverent (not "ready," as printed in the report) seeker after truth.

Books of "Any Questions?"-The second and third volumes of "Any Questions?" are available, price 7s. 6d. (postage 6d.), from the Publishing Manager, B.M.A. House, Tavistock Square. London, W.C.1, or through any bookseller. Each contains some 200 selected expert answers, and the third volume a cumulative index to the three published books.

All communications with regard to editorial business shouid be addressed to THE EDITOR, British MEdical Journal. B.M.A. House, Tavistock SOUARE. LONDON, W.C.1. TELEPHONE: EUSTON 4499. TELEGRAMS: Aitiology, Westcent, London. ORIGINAL ARTICLES AND LETTERS forwarded for publication are understood to be offered to the British Medical Journal alone unless the contrary be stated.

Authors desiring REPRINTS should communicate with the Publishing Manager, B.M.A. House, Tavistock Square, W.C.1, on receipt of proofs. Authors overseas should indicate on MSS. if reprints are required, as proofs are not sent abroad.

ADVERTISEMENTS should be addressed to the Advertisement Director B.M.A. House, Tavistock Square. London, W.C.1 (hours 9 a.m. to 5 p.m.). TELEPHONE: EUSTON 4499. TELEGRAMS: Britmedads, Westcent, London.

MEMBERS' SUBSCRIPTIONS should be sent to the SECRETARY of the Association. TELEPHONE: EUSTON 4499. TELEgRAMS: Medisecra. Westcent, London.

B.M.A. Scottish Office: 7, Drumsheugh Gardens, Edinburgh. 